Research article

Open Access

\title{
Effects of combined treatment with rapamycin and cotylenin $A$, a novel differentiation-inducing agent, on human breast carcinoma MCF-7 cells and xenografts
}

\author{
Takashi Kasukabe ${ }^{1}$, Junko Okabe-Kado ${ }^{1}$, Nobuo Kato ${ }^{2}$, Takeshi Sassa ${ }^{3}$ and Yoshio Honma ${ }^{1,4}$
}

\author{
${ }^{1}$ Research Institute for Clinical Oncology, Saitama Cancer Center, Saitama, Japan \\ 2The Institute of Scientific and Industrial Research, Osaka University, Osaka, Japan \\ ${ }^{3}$ Department of Bioresource Engineering, Yamagata University, Tsuruoka, Japan \\ ${ }^{4}$ School of Medicine, Shimane University, Izumo, Japan \\ Corresponding author: Takashi Kasukabe, kasukabe@cancer-c.pref.saitama.jp
}

Received: 22 Apr 2005 Revisions requested: 23 Jun 2005 Revisions received: 22 Sep 2005 Accepted: 6 Oct 2005 Published: 9 Nov 2005

Breast Cancer Research 2005, 7:R1097-R1110 (DOI 10.1186/bcr1344)

This article is online at: http://breast-cancer-research.com/content/7/6/R1097

(c) 2005 Kasukabe et al.; licensee BioMed Central Ltd.

This is an open access article distributed under the terms of the Creative Commons Attribution License (http://creativecommons.org/licenses/by/2.0), which permits unrestricted use, distribution, and reproduction in any medium, provided the original work is properly cited.

\begin{abstract}
Introduction Rapamycin, an inhibitor of the serine/threonine kinase target of rapamycin, induces $\mathrm{G}_{1}$ arrest and/or apoptosis. Although rapamycin and its analogues are attractive candidates for cancer therapy, their sensitivities with respect to growth inhibition differ markedly among various cancer cells. Using human breast carcinoma cell line MCF-7 as an experimental model system, we examined the growth-inhibitory effects of combinations of various agents and rapamycin to find the agent that most potently enhances the growth-inhibitory effect of rapamycin.
\end{abstract}

Method We evaluated the growth-inhibitory effect of rapamycin plus various agents, including cotylenin A (a novel inducer of differentiation of myeloid leukaemia cells) to MCF-7 cells, using either MTT assay or trypan blue dye exclusion test. The cell cycle was analyzed using propidium iodide-stained nuclei. Expressions of several genes in MCF-7 cells with rapamycin plus cotylenin A were studied using cDNA microarray analysis and RT-PCR. The in vitro results of MCF-7 cells treated with rapamycin plus cotylenin $\mathrm{A}$ were further confirmed in vivo in a mouse xenograft model.
Results We found that the sensitivity of rapamycin to MCF-7 cells was markedly affected by cotylenin A. This treatment induced growth arrest of the cells at the $G_{1}$ phase, rather than apoptosis, and induced senescence-associated $\beta$ galactosidase activity. We examined the gene expression profiles associated with exposure to rapamycin and cotylenin $A$ using cDNA microarrays. We found that expressions of cyclin $\mathrm{G}_{2}$, transforming growth factor- $\beta$-induced $68 \mathrm{kDa}$ protein, BCL2-interacting killer, and growth factor receptor-bound 7 were markedly induced in MCF-7 cells treated with rapamycin plus cotylenin A. Furthermore, combined treatment with rapamycin and cotylenin A significantly inhibited the growth of MCF-7 cells as xenografts, without apparent adverse effects. Conclusion Rapamycin and cotylenin A cooperatively induced growth arrest in breast carcinoma MCF-7 cells in vitro, and treatment with rapamycin and cotylenin A combined more strongly inhibited the growth of MCF-7 cells as xenografts in vivo than treatment with rapamycin or cotylenin $A$ alone, suggesting that this combination may have therapeutic value in treating breast cancer. We also identified several genes that were markedly modulated in MCF-7 cells treated with rapamycin plus cotylenin A.

\section{Introduction}

Breast cancer is the most frequent cancer disease among women in the Western world, accounting for almost $30 \%$ of all cancers among women. Although there have been advances in the areas of early detection and treatment, the incidence of this disease has increased and mortality rates are almost unaltered [1]. Because oestrogen exposure is considered to be a major factor in the development of breast cancer and because most breast cancers maintain their hormonal dependency, the nonsteroidal antioestrogen tamoxifen has been the leading

$\mathrm{BIK}=\mathrm{BCL} 2$-interacting killer; $\mathrm{Cl}=$ combination index; $\mathrm{CN}-\mathrm{A}=$ cotylenin $\mathrm{A} ; \mathrm{EGR}=$ early growth response; FKBP12 = FK506-binding protein; GAPDH $=$ glyceraldehyde-3-phosphate dehydrogenase; GRB = growth factor receptor-bound; $\mathrm{mTOR}=$ mammalian target of rapamycin; MTT = 3-(4,5dimethylthiazol-2-yl)-2,5-diphenyltetrazolium bromide; $\mathrm{PBS}=$ phosphate-buffered saline; RT-PCR = reverse transcription polymerase chain reaction; $\mathrm{SA}-\beta \mathrm{Gal}=$ senescence-associated $\beta$-galactosidase; TGFBI $=$ transforming growth factor- $\beta$-induced $68 \mathrm{kDa}$ protein. 
drug in the treatment of advanced breast cancer for more than 30 years. However, the development of resistance to antihormonal therapy is a major problem in the treatment of breast cancer patients $[2,3]$. Therefore, the development of a new strategy for suppressing the growth of breast cancer cells is required.

Rapamycin and its analogues are promising new drugs that use alternative mechanisms to inhibit the growth of breast cancer cells [4,5]. Rapamycin, a macrolide fungicide, was first isolated from Streptomyces hygroscopicus in the early 1970s and was initially developed clinically for its immunosuppressant properties. Subsequently, rapamycin became of significant interest as a potential antitumour drug.

Rapamycin first binds the 12-kDa immunophilin FK506-binding protein (FKBP12), and this complex then inhibits mammalian target of rapamycin (mTOR) - a serine/threonine kinase. mTOR is recognized as a central controller of eukaryotic cell growth and proliferation, in that it senses nutritional status and mitogens in mammalian cells and allows for the progression from $G_{1}$ to $S$ phase, although it may not be the only target of rapamycin. Clinically, rapamycin analogues with improved stability and pharmacological properties have been well tolerated by patients in phase I trials, and these agents have exhibited a promising antitumour effect in several types of refractory tumour, including breast cancer $[6,7]$. However, the sensitivities of rapamycin with respect to growth inhibition differ markedly among various cancer cells, and only a minority of patients in each tumour lineage appear to respond to rapamycin analogues [5]. To improve therapeutic efficacy against a broad range of human tumour cells, we must develop new and potent derivatives of rapamycin. Alternatively, application of synergistic combinations of rapamycin and some agents may lead to a potent therapy for some types of solid tumours.

Differentiation-inducing agents can alter the phenotype of cancer cells, including their sensitivity to anticancer drugs. We previously reported that treatment with hemin, an inducer of erythroid differentiation, greatly increased the sensitivity of human myeloid leukaemia K562 cells to 1- $\beta$-d-arabinofuranosylcytosine, and that erythroid differentiation factor (activin A) enhanced the sensitivity of multidrug-resistant leukaemia cells to vincristine, actinomycin $D$ and doxorubicin $[8,9]$. In the present investigation, we examined the synergistic effects of various differentiation-inducing agents and rapamycin on the growth of mammary carcinoma cells to identify the most potent and clinically applicable drugs. The most effective agent was cotylenin A (CN-A), which has a novel fusicoccane-diterpene glycoside with a complex sugar moiety. It was originally isolated as a plant growth regulator, and has been shown to affect several physiological processes in higher plants and to have differentiation-inducing activity in several human and murine myeloid cell lines [10-14]. In leukaemia cells that were freshly isolated from patients with acute myelogenous leukae- mia, CN-A has also been found to affect the differentiation of cells in primary culture [15]. This differentiation-inducing activity was more potent than those of all-trans retinoic acid and $1 \alpha, 25$-dihydroxyvitamin $D_{3}$.

Apart from the potent differentiation-inducing activity in vitro, the administration of $\mathrm{CN}-\mathrm{A}$ also significantly prolonged the survival of mice with severe combined immunodeficiency that had been inoculated with cells of human promyelocytic leukaemia cell line NB4 [16]. No appreciable adverse effects were observed with this treatment, suggesting that $\mathrm{CN}-\mathrm{A}$ may be useful in treating leukaemia and other malignancies.

Recently, we found that $\mathrm{CN}-\mathrm{A}$ and interferon- $\alpha$ synergistically inhibited growth and induced apoptosis in several human nonsmall-cell lung carcinoma cell lines. Furthermore, this combined treatment markedly inhibited the growth of human lung cancer cells as xenografts [17]. In the present study, we found that treatment with the combination of rapamycin and $\mathrm{CN}-\mathrm{A}$ synergistically inhibited the proliferation of human breast cancer MCF- 7 cells in vitro, and that this combined treatment also induced growth arrest of the cells at $G_{1}$ phase, rather than inducing apoptosis. We also identified several genes that were markedly modulated in MCF-7 cells treated with rapamycin plus CN-A. Furthermore, we examined the therapeutic effects on xenografts of human breast carcinoma cells.

\section{Materials and methods Materials}

Rapamycin was purchased from Sigma Chemical (St. Louis, MO, USA). CN-A was purified from a stock ethyl acetate extract obtained from the culture filtrate of Cladosporium fungus sp. 501-7W by flash chromatography on silica gel with more than $99 \%$ purity $[10,11]$. A stock solution of $\mathrm{CN}-\mathrm{A}$ was prepared in absolute ethanol at $20 \mathrm{mg} / \mathrm{ml}$.

\section{Cells and cell culture}

Human breast carcinoma cell lines (MCF-7, T-47D and MDAMB-231) and human promyeloblastic leukaemia cell line NB-4 were cultured in RPMI 1640 supplemented with 10\% foetal bovine serum at $37^{\circ} \mathrm{C}$ in a humidified atmosphere of $5 \%$ carbon dioxide in air.

\section{Assay of cell growth}

The cells were seeded at $1-3 \times 10^{4} / \mathrm{ml}$ in a 24 -well multidish. After culture with or without the test compounds for the indicated times, viable cells were examined using either the trypan blue dye exclusion test or a modified MTT (3-(4,5-dimethylthiazol-2-yl)-2,5-diphenyltetrazolium bromide) assay. In the MTT assay, $100 \mu \mathrm{l}$ MTT solution ( $1 \mathrm{mg} / \mathrm{ml}$ in PBS) was added to each well and cells were incubated for 4 hours. The cells were then centrifuged at $1000 \mathrm{~g}$ for $10 \mathrm{~min}$ and the precipitates were dissolved in $1 \mathrm{ml}$ dimethyl sulphoxide; their absorption at $560 \mathrm{~nm}$ was determined. Assay of the cumulative cell number was determined as described elsewhere [17]. 


\section{Analysis of the effects of combinations of drugs}

Isobologram analysis was used to determine the effects of combinations of drugs on MCF-7 cells. Dose-dependent effects were determined for each compound and for one compound with fixed concentrations of another. The interaction of two compounds was quantified by determining the combination index $(\mathrm{Cl})$, in accordance with the following classic isobologram [18]:

$\mathrm{Cl}=(\mathrm{D})_{1} /(\mathrm{Dx})_{1}+(\mathrm{D})_{2} /(\mathrm{Dx})_{2}$

Where $D x$ is the dose of one drug alone required to produce an effect, and (D) ${ }_{1}$ and (D) ${ }_{2}$ are the doses of compounds 1 and 2 , respectively, in combination that produce the same effect. From this analysis, the combined effects of the two drugs can be summarized as follows: $\mathrm{Cl}=1$ indicates summation (additive and zero interaction); $\mathrm{Cl}<1$ indicates synergism; and $\mathrm{Cl}$ $>1$ indicates antagonism.

\section{Cell cycle analysis}

The cell cycle was analyzed using propidium iodide-stained nuclei. Samples of $2 \times 10^{6}$ cells were harvested at the time points indicated, washed in ice-cold PBS, fixed by the addition of $100 \%$ ethanol and left for $30 \mathrm{~min}$ on ice. The cell pellet was washed and suspended in $200 \mu \mathrm{l} 1.12 \%$ sodium citrate containing RNase A $(250 \mu \mathrm{g} / \mathrm{ml})$ for $30 \mathrm{~min}$ at room temperature. Thereafter, the cells were stained with $50 \mu \mathrm{g} / \mathrm{ml}$ propidium iodide in the presence of $1.12 \%$ sodium citrate and analyzed in a fluorescence-activated cell sorter.

\section{Assay of E-cadherin and senescence markers}

The expression of E-cadherin was detected by immunocytochemistry. Cells were fixed in $4 \%$ paraformaldehyde in PBS and permeabilized in acetone at $4^{\circ} \mathrm{C}$. Slides were pretreated in PBS containing $0.2 \%$ Tween-20, blocked with $5 \%$ normal goat serum and $0.2 \%$ Tween-20 in PBS, and incubated with rabbit polyclonal antibody to E-cadherin (Santa Cruz, CA, USA). Antibody-antigen complexes were visualized using
DAKO ENVISION/AP kit (DakoCytomation Japan, Kyoto, Japan). Senescence-associated $\beta$-galactosidase (SA- $\beta$ Gal) activity was determined as described by Dimri and coworkers [19]. SA- $\beta$ Gal activity was monitored visually by scoring blue precipitate in the cytoplasm.

\section{cDNA microarray analysis}

Total RNA was isolated from MCF-7 cells treated with or without compound for 12 hours using Isogen (Nippon Gene, Toyama, Japan) [20]. Poly(A)+RNA was reverse transcribed with the concomitant incorporation of Cy3- and Cy5-labelled nucleotides. The labelled probes were hybridized with a cDNA microarray, representing about 16,000 different human genes (TaKaRa Bio Inc., Tokyo, Japan), and their fluorescent intensities were scanned according to the protocol standardized by TaKaRa Bio Inc. The genes were screened by analyzing the difference in expression profiles between two genes.

\section{Gene expression analysis by RT-PCR}

Total RNA was extracted using Isogen (Nippon Gene), in accordance with the manufacturer's instructions. Total RNA (1 $\mu \mathrm{g})$ from tumour cells was converted to first-strand cDNA primed with random nonamer in a reaction volume of $20 \mu \mathrm{l}$ using an RNA PCR kit (TaKaRa Bio), and $4 \mu$ of this reaction was used as a template in the PCR. The oligonucleotides used in PCR amplification are summarized in Table 1. PCR consisted of 25 cycles for transforming growth factor- $\beta$-induced $68 \mathrm{kDa}$ protein (TGFBI), BCL2-interacting killer (BIK) and early growth response (EGR)3; 22 cycles for cyclin $\mathrm{G}_{2} ; 27$ cycles for growth factor receptor-bound (GRB)7; and 17 cycles for glyceraldehyde-3-phosphate dehydrogenase (GAPDH); with denaturing at $94^{\circ} \mathrm{C}$ for $30 \mathrm{~s}$, annealing at $60^{\circ} \mathrm{C}$ for $30 \mathrm{~s}$ and extension at $72^{\circ} \mathrm{C}$ for $30 \mathrm{~s}$. The linearity of the quantitation of RT-PCR products was determined using $[\alpha-$ $\left.{ }^{32} \mathrm{P}\right] \mathrm{dCTP}$ and various amounts of total RNA, as described in the literature [20]. Under these conditions, the amounts of PCR products increased linearly up to $0.4 \mu \mathrm{g}$ total RNA.

Table 1

\begin{tabular}{lll}
\multicolumn{2}{l}{ Oligonucleotides used in PCR amplification } & \\
\hline TGFBI & Sense strand & Antisense strand \\
BIK & 5'-TGTGTGCTGTGCAGAAGGTT-3' & 5'-ATATGGTAGCGGAGGGCATT-3' \\
Cyclin G & 5'-CTCCAGAGACATCTTGATGG-3' & 5'-TGGGATCTCCAGAACCTCATT-3' \\
GRB7 & 5'-AGCACTTGGCAGGTCATGAA-3' & 5'-CAACTATTCTAGCAGCCAGC-3' \\
EGR3 & 5'-TCTGCCTGAGGAGGTAAAGA-3' & 5'-GGAGCTCTTGAACAGTTCGT-3' \\
GAPDH & 5'-CTACTTGGGAAAGTTCGCCT-3' & 5'-GAATGCCTTGATGGTCTCCA-3' \\
\hline
\end{tabular}

BIK, BCL2-interacting killer; EGR, early growth response; GAPDH, glyceraldehyde-3-phosphate dehydrogenase; GRB, growth factor receptorbound; TGFBI, transforming growth factor- $\beta$-induced $68 \mathrm{kDa}$ 


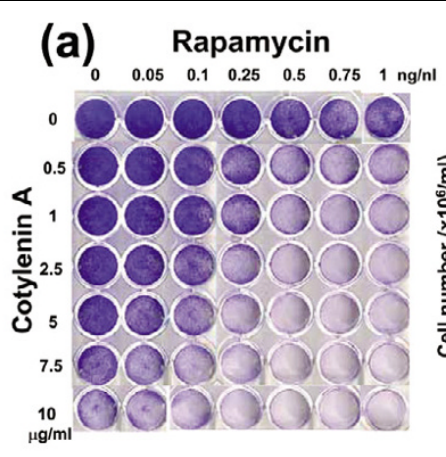

(b)

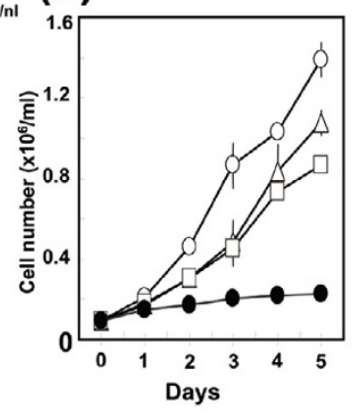

(c)

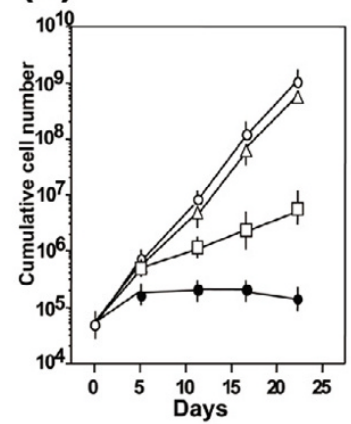

Synergistic effects of rapamycin and CN-A on the growth of MCF-7 cells. (a) Cells $\left(3 \times 10^{4} \mathrm{cell} / \mathrm{s} / \mathrm{ml}\right)$ were cultured with various concentrations of rapamycin and CN-A for 5 days. After culture, cells were stained with May-Grunwald-Giemsa. (b) Cells $\left(3 \times 10^{4}\right.$ cells $\left./ \mathrm{ml}\right)$ were cultured without (white circle) or with (white triangle) $0.5 \mathrm{ng} / \mathrm{ml}$ rapamycin, $10 \mu \mathrm{g} / \mathrm{ml} \mathrm{CN}-\mathrm{A}$ (white square), or $0.5 \mathrm{ng} / \mathrm{ml}$ rapamycin plus $10 \mu \mathrm{g} / \mathrm{ml} \mathrm{CN-A} \mathrm{(black} \mathrm{circle)}$ for the indicated number of days. The values are expressed as mean \pm standard deviation of four determinations. (c) Cells were cultured without (white circle) or with (white triangle) $0.5 \mathrm{ng} / \mathrm{ml}$ rapamycin, $10 \mu \mathrm{g} / \mathrm{ml} \mathrm{CN}-\mathrm{A}$ (white square), or $0.5 \mathrm{ng} / \mathrm{ml}$ rapamycin plus $10 \mu \mathrm{g} / \mathrm{ml} \mathrm{CN-A} \mathrm{(black} \mathrm{circle)}$ for the indicated number of days. The culture medium was replaced by fresh medium at least once every 5 days. The cell density was kept at $1-8 \times$ $10^{4} \mathrm{cells} / \mathrm{ml}$. The values are expressed as mean \pm SD of four separate experiments. CN-A, cotylenin A.

\section{Transplantation of MCF-7 cells into nude mice and treatment}

Female athymic nude mice with a BALB/c genetic background were supplied by CLEA Japan (Tokyo, Japan). They were housed under specific pathogen-free conditions. The in vivo experiments were performed in accordance with the guidelines of our institute (Guide for Animal Experimentation, Saitama Cancer Center, Saitama, Japan). One week before MCF-7 cell inoculation, mice each received $2 \mu \mathrm{g}$ of $17 \beta$ oestradiol valerate (Sigma), dissolved in $0.2 \mathrm{ml}$ of sesame oil, by subcutaneous injection. Oestrogen injections were repeated every week to sustain tumour growth. Mice were inoculated subcutaneously with $2 \times 10^{7} \mathrm{MCF}-7$ cells. By day 21 after inoculation, all of the tumours were about the same size. The animals were randomly distributed into four groups of 20 mice each. A stock solution of $\mathrm{CN}-\mathrm{A}$ for administration was prepared in dimethyl sulphoxide at $100 \mathrm{mg} / \mathrm{ml}$, and rapamycin was dissolved in ethanol at $1 \mathrm{mg} / \mathrm{ml}$. Mice were given a daily intraperitoneal injection of $0.1 \mathrm{ml} \mathrm{PBS}$, including $100 \mathrm{ng}$ rapamycin, and/or subcutaneous injections every other day of $0.2 \mathrm{ml}$ of PBS, including $100 \mu \mathrm{g} \mathrm{CN-A}$, at a site distant from the tumours. Tumour size was measured with vernier calipers every other day. Statistical analysis was performed using Student's t-test.

\section{Results}

\section{Combined effects of rapamycin and cotylenin A on the growth of MCF-7 cells}

We examined the synergistic effects of various agents, including differentiation inducers and rapamycin, on growth inhibition of cells of breast cancer cell line MCF-7. Sensitivity to anticancer agents such as 5-fluorouracil, cisplatin and doxorubicin was barely affected by rapamycin. All-trans retinoic acid (a typical differentiation inducer), but not vitamin $D_{3}$, affected
Figure 2

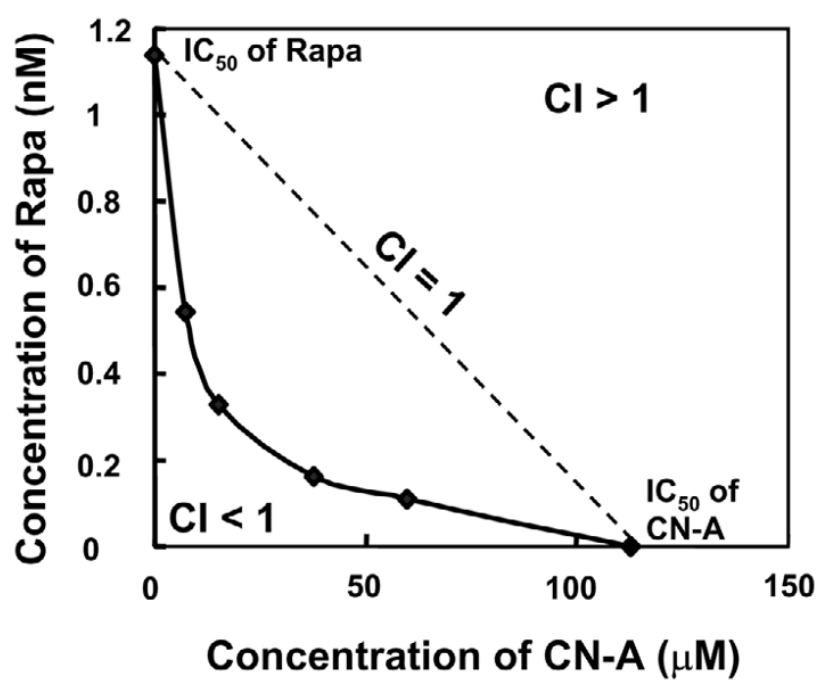

Classic isobologram at $\mathrm{IC}_{50}$ : rapamycin plus $\mathrm{CN}-\mathrm{A}$ in MCF-7 cells. Isoboles for the combination of rapamycin with $\mathrm{CN}-\mathrm{A}$ that were isoeffective $\left(\mathrm{IC}_{50}\right)$ for inhibition of proliferation of MCF-7 cells. The dashed line indicates the zero interaction of the isobole. Cells $\left(3 \times 10^{4} \mathrm{cells} / \mathrm{ml}\right)$ were treated with rapamycin and CN-A for 5 days. Values are the means of three separate experiments. CN-A, cotylenin $A ; I_{50}$, the concentration of the drug required for $50 \%$ inhibition of cell growth.

the growth of MCF-7 cells, and the growth-inhibitory effect of rapamycin was significantly enhanced by all-trans retinoic acid, although a high concentration of retinoic acid was required (data not shown).

Among the differentiation-inducing agents tested, the sensitivity of MCF-7 cells to rapamycin was most affected by $\mathrm{CN}-\mathrm{A}$, a novel inducer of the differentiation of myeloid leukaemia [12- 

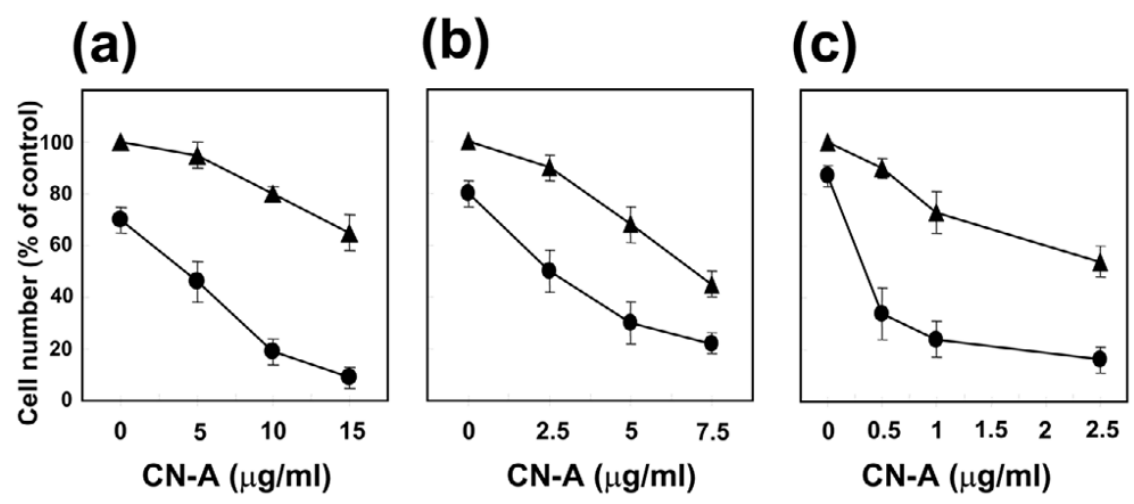

Combined effect of rapamycin and CN-A on the growth of human cancer cells. (a) human breast cancer T-47D cells $\left(3 \times 10^{4}\right.$ cells $\left./ \mathrm{ml}\right)$ were treated with CN-A in the absence (black triangle) or the presence (black circle) of $0.5 \mathrm{ng} / \mathrm{ml}$ rapamycin for 5 days. (b) human breast cancer MBA-MB-231 $\left(3 \times 10^{4}\right.$ cells $/ \mathrm{ml}$ ) cells were treated with CN-A in the absence (black triangle) or the presence (black circle) of $15 \mathrm{ng} / \mathrm{ml}$ rapamycin for 5 days. (c) human promyelocytic leukaemia NB-4 cells $\left(3 \times 10^{4} \mathrm{cells} / \mathrm{ml}\right)$ were treated with CN-A in the absence (black triangle) or the presence (black circle) of $0.5 \mathrm{ng} / \mathrm{ml}$ rapamycin for 5 days. Values are expressed as mean \pm standard deviation for three separate experiments. CN-A, cotylenin $A$.

16]. Figure 1 shows the synergistic effects of rapamycin and $\mathrm{CN}-\mathrm{A}$ on the growth of MCF-7 cells. Figure 1a shows the May-Gruenwald-Giemsa staining pattern of MCF-7 cells after 5-days of treatment with various concentrations of both rapamycin and $\mathrm{CN}-\mathrm{A}$. Figure $1 \mathrm{~b}$ shows the time course of the combined effects of rapamycin and $\mathrm{CN}-\mathrm{A}$ on the growth of MCF-7 cells. The growth of MCF-7 cells was inhibited moderately by rapamycin $(0.5 \mathrm{ng} / \mathrm{ml})$ or $\mathrm{CN}-\mathrm{A}(10 \mu \mathrm{g} / \mathrm{ml})$ alone, but growth was still seen at least until 5 days, whereas the cell number did not change after 1 day of treatment with the combination of rapamycin and $\mathrm{CN}-\mathrm{A}$. Figure 2 shows isoboles for the combination of rapamycin with $\mathrm{CN}-\mathrm{A}$ that were isoeffective $\left(\mathrm{IC}_{50}\right.$ : the concentration of the drug required for $50 \%$ inhibition of cell growth) for inhibition of proliferation of MCF-7 cells. These isoboles indicate that the combination of these drugs had synergistic effects.

We also examined the long-term effects of combined treatment with rapamycin and $\mathrm{CN}-\mathrm{A}$ on the proliferation of MCF-7 cells (Fig. 1c). The growth rate of rapamycin-treated cells was almost the same as that of control cells after 5 days. Cell growth was significantly inhibited by $\mathrm{CN}-\mathrm{A}$ alone after 5 days, but the cell number was still increased even at day 23. On the other hand, cell growth was greatly inhibited by combined treatment with rapamycin and $\mathrm{CN}-\mathrm{A}$, and the cell number at day 23 was almost the same as that at day 5 (Fig. 1c).

Similar growth-inhibitory effects of rapamycin and CN-A were observed in two other human breast cancer cell lines (oestrogen receptor-positive T-47D cells and oestrogen receptornegative MDA-MB-231 cells; Fig. 3a,b). Furthermore, these combined effects of rapamycin and $\mathrm{CN}-\mathrm{A}$ were also observed in several different tumour cell lines such as human promyelocytic leukaemia NB-4 cells (Fig. 3c) and human non-small-cell lung carcinoma A549 and Lu99 cells (data not shown). These findings indicate that the growth-inhibitory effects of rapamycin plus CN-A were not restricted to MCF-7 cells.

To establish the most effective treatment procedure using rapamycin and $\mathrm{CN}-\mathrm{A}$ on MCF-7 cells, we examined the effects of various different treatments on MCF-7 cells. MCF- 7 cells were seeded at $1 \times 10^{4} \mathrm{cells} / \mathrm{ml}$ and the number of viable cells was determined by MTT assay after 7 days. Simultaneous treatment with rapamycin $(0.5 \mathrm{ng} / \mathrm{ml})$ and $\mathrm{CN}-\mathrm{A}(2.5 \mu \mathrm{g} / \mathrm{ml})$ for 7 days was most effective at inhibiting cell proliferation $(96 \%$ inhibition). Furthermore, we found that the timing of the addition of CN-A was critical to the inhibitory affect on the cell number. When CN-A was added at day 2, the combined growth-inhibitory effect was markedly decreased at 7 days (29\% inhibition). On the other hand, when rapamycin was added at day 1 or day 2 , the combined growth-inhibitory effects were almost completely conserved at 7 days (95\% or $90 \%$ inhibition, respectively). We also found that an initial short exposure to $\mathrm{CN}-\mathrm{A}$ was enough to exert the combined effect. When cells were treated with $\mathrm{CN}-\mathrm{A}$ for only 1 day from day 0 to day 1 in the presence of rapamycin, and then cultured only in the presence of rapamycin from day 2 to day 7, the combined growth-inhibitory effects were still almost completely preserved at 7 days ( $90 \%$ inhibition). These findings indicate that simultaneous treatment with rapamycin and $\mathrm{CN}$ $A$ is the most effective procedure for inhibiting the cell growth of MCF-7 cells and that initial 1-day treatment with CN-A and continuous treatment with rapamycin has almost the same growth-inhibitory effects as simultaneous treatment with rapamycin and $\mathrm{CN}-\mathrm{A}$.

\section{Induction of $\mathbf{G}_{\mathbf{1}}$ arrest in MCF-7 cells treated with rapamycin plus cotylenin $A$}

To better understand the combined effects of rapamycin and CN-A on cell growth, we exposed MCF-7 cells to $0.5 \mathrm{ng} / \mathrm{ml}$ 
Figure 4
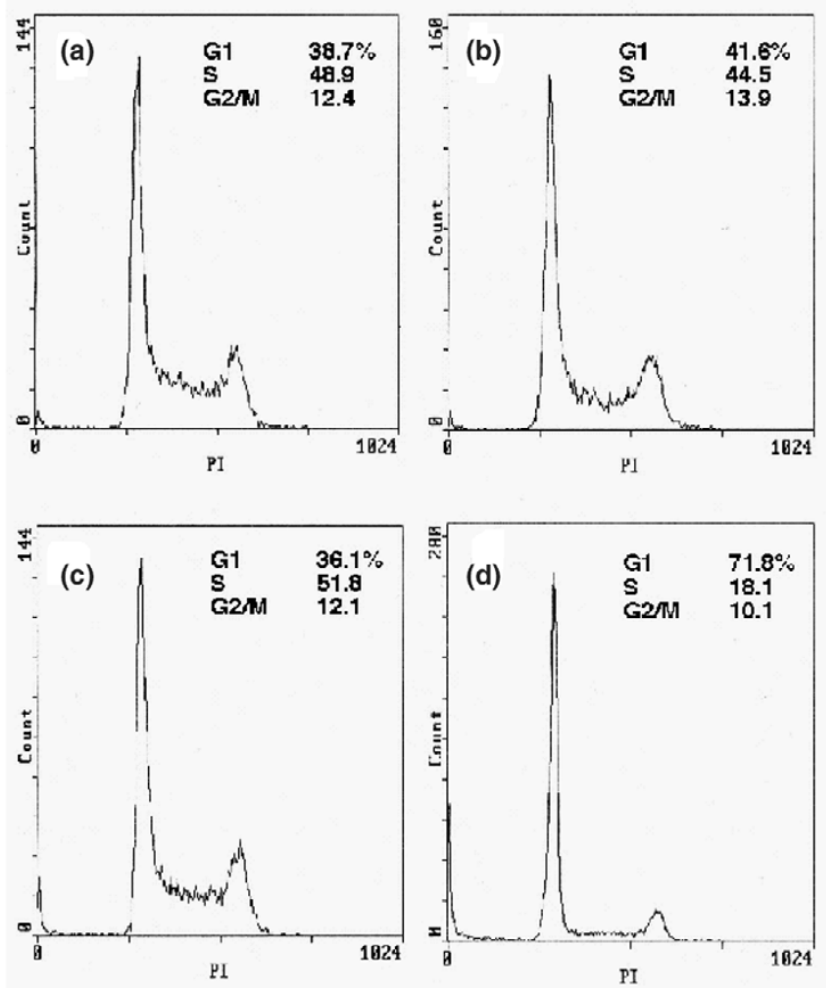

Induction of $\mathrm{G}_{1}$ arrest in MCF-7 cells treated with rapamycin plus $\mathrm{CN}-\mathrm{A}$. Cells were cultured (a) without or (b) with $10 \mu \mathrm{g} / \mathrm{ml} \mathrm{CN-A,} \mathrm{(c)} 0.5 \mathrm{ng} /$ $\mathrm{ml}$ rapamycin, or (d) $0.5 \mathrm{ng} / \mathrm{ml}$ rapamycin plus $10 \mu \mathrm{g} / \mathrm{ml} \mathrm{CN-A}$ for 6 days, and DNA histograms were then analyzed. $\mathrm{CN}-\mathrm{A}$, cotylenin $\mathrm{A}$.

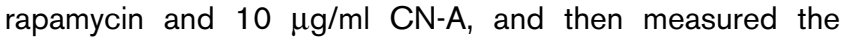
changes in the cell cycle distribution after 6 days. This concentration of rapamycin or $\mathrm{CN}-\mathrm{A}$ alone did not affect the cell cycle in our study, whereas rapamycin with $\mathrm{CN}-\mathrm{A}$ induced growth arrest of cells at the $G_{1}$ phase (Fig. 4). The induction of apoptosis (cells in sub- $G_{1}$ phase) was not observed in cells with the combined treatment.

\section{Induction of phenotypic changes in MCF-7 cells treated with rapamycin and cotylenin $A$}

Because treatment with rapamycin and $C N-A$ induced $G_{1}$ arrest but not apoptosis, these treatments may induce phenotypic changes in MCF-7 cells. Changes in several differentiation-associated phenotypes were examined, but the expression of casein or mucin was not significantly induced by the combined treatment. Intracellular accumulation of lipid droplets was also not observed (data not shown). However, when we cultured MCF- 7 cells for 7 days, CN-A greatly enhanced the expression of E-cadherin, and the expression was significantly enhanced by rapamycin (Fig. 5). We also found that $\mathrm{CN}-\mathrm{A}$ alone or $\mathrm{CN}-\mathrm{A}$ plus rapamycin could induce activity of SA- $\beta$ Gal (Fig. 5), which is one of the markers of senescence of epithelial cells [21]. These findings suggest that this combined treatment with rapamycin and $\mathrm{CN}-\mathrm{A}$
Figure 5
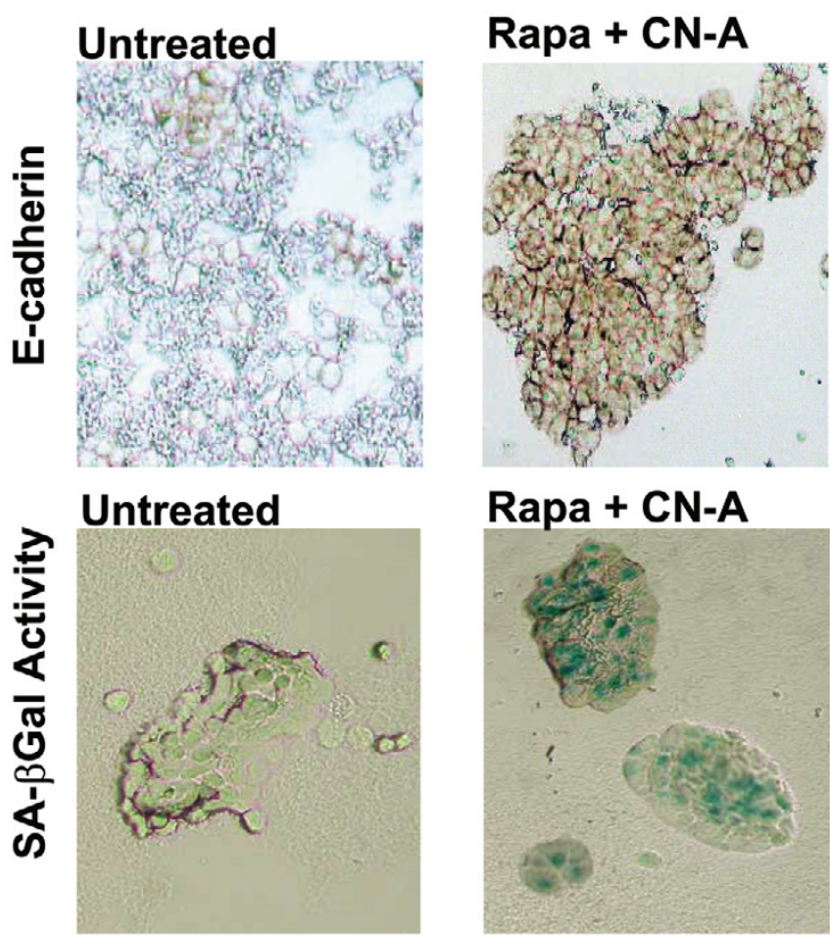

Induction of phenotypic changes in MCF-7 cells treated with CN-A and rapamycin. Upper row: E-cadherin. Cells were cultured in the presence (right) or absence (left) of $10 \mu \mathrm{g} / \mathrm{ml} \mathrm{CN-A} \mathrm{plus} 0.5 \mathrm{ng} / \mathrm{ml}$ of rapamycin for 7 days. Lower row: SA- $\beta$ Gal activity. Cells were cultured in the presence (right) or absence (left) of $10 \mu \mathrm{g} / \mathrm{ml} \mathrm{CN}-A$ plus $0.5 \mathrm{ng} / \mathrm{ml}$ rapamycin for 7 days. CN-A, cotylenin A; Rapa, rapamycin; SA- $\beta$ Gal, senescence-associated $\beta$-galactosidase.

induced growth arrest of cells at the $\mathrm{G}_{1}$ phase and may induce phenotypic changes toward cell senescence but not apoptosis.

\section{Effects of the combined treatment with rapamycin plus cotylenin A on expression of p53, p21Cip1, p27Kip1 and cyclins}

To elucidate the mechanism underlying the $G_{1}$ arrest mediated by rapamycin plus $\mathrm{CN}-\mathrm{A}$, we then examined the expression of several genes, using RT-PCR, that are important for cell cycle regulation. We first examined the expression of p53 in MCF-7 cells (Fig. 6a). Unexpectedly, the expression of p53 was not affected when MCF-7 cells were treated with $1 \mathrm{ng} / \mathrm{ml}$ rapamycin alone, $2.5-10 \mu \mathrm{g} / \mathrm{ml} \mathrm{CN-A}$ alone, or $1 \mathrm{ng} / \mathrm{ml}$ rapamycin plus $2.5 \mu \mathrm{g} / \mathrm{ml} \mathrm{CN-A}$ for 24 hours. HL60 cells were used as a negative control for p53 expression.

Because the $\mathrm{p} 21^{\mathrm{Cip} 1}$ and $\mathrm{p} 27^{\mathrm{Kip} 1} \mathrm{Cdk}$ inhibitors play important roles in cell cycle regulation, especially in response to external agents, we then examined the levels of expression of these

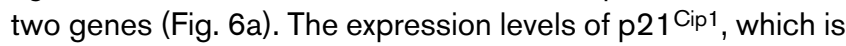
a target gene of p53, and p27Kip1 were also not induced by these treatments. Cyclin $D_{1}$ plays an important role in $G_{1}$ 
Figure 6

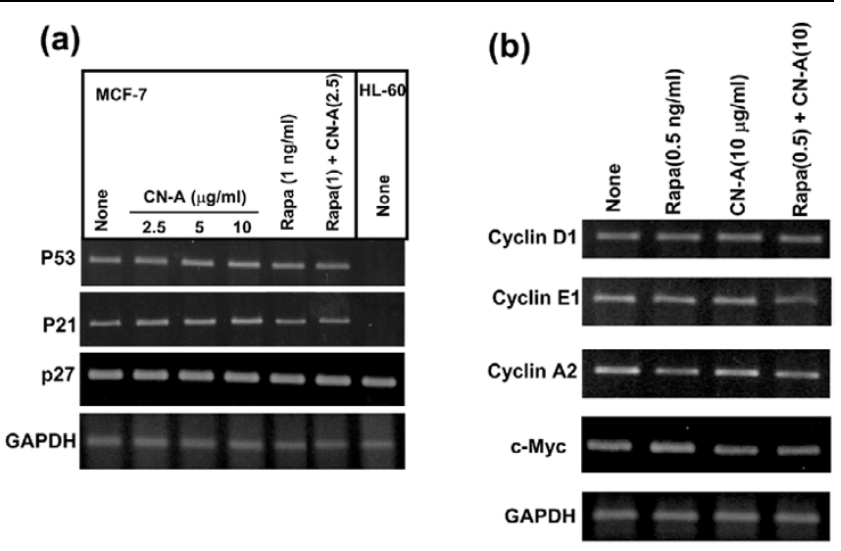

Effects of rapamycin and CN-A on the expressions of p53, p21Cip1, p27Kip1 and cyclins. Expression of mRNAs was examined by RT-PCR analysis. (a) MCF-7 cells were cultured with $2.5-10 \mu \mathrm{g} / \mathrm{ml} \mathrm{CN}-\mathrm{A}$ or 1 $\mathrm{ng} / \mathrm{ml}$ rapamycin, or both combined for 24 hours. (b) MCF-7 cells were cultured with $0.5 \mathrm{ng} / \mathrm{ml}$ rapamycin or $10 \mu \mathrm{g} / \mathrm{ml} \mathrm{CN}-\mathrm{A}$, or both combined for 12 hours. The levels of GAPDH expression are shown to demonstrate that equal amounts of RNA were used for RT-PCR. CN-A, cotylenin A; GAPDH, glyceraldehyde-3-phosphate dehydrogenase.

phase cell cycle progression, and previous work demonstrated that rapamycin decreased expression of cyclin $D_{1}$ and c-myc [22]. When MCF-7 cells were treated with 0.5 $\mathrm{ng} / \mathrm{ml}$ rapamycin and $10 \mu \mathrm{g} / \mathrm{ml} \mathrm{CN}-\mathrm{A}$ for 12 hours, expression of cyclin $D_{1}$ or $c$-myc was not inhibited by the combined treatments (Fig. 6b). On the other hand, expression of cyclin $E_{1}$ was slightly inhibited by the combined treatments (Fig. 6b).

\section{CDNA microarray analysis of MCF-7 cells treated with rapamycin, cotylenin $A$, and rapamycin + cotylenin $A$}

Because we could not detect major changes in the expression of cell cycle regulating genes using RT-PCR (Fig. 6), we conducted a cDNA microarray analysis of MCF-7 cells and screened genes that were upregulated or downregulated by rapamycin plus $\mathrm{CN}-\mathrm{A}$. MCF-7 cells were cultured with $0.5 \mathrm{ng} /$ $\mathrm{ml}$ rapamycin or $10 \mu \mathrm{g} / \mathrm{ml} \mathrm{CN-A}$, or both combined for 12 hours and total RNA was used in the microarray analysis. When MCF- 7 cells were cultured with the same treatments for 5 -day, the levels of growth inhibition induced by rapamycin, $\mathrm{CN}-\mathrm{A}$, and rapamycin plus CN-A were 31\%, 40\% and 90\%, respectively.

Genes with a treatment:control ratio greater than 2 were considered to be significantly upregulated, and those with a ratio below 0.5 were considered to be significantly downregulated. Many more genes were upregulated and downregulated upon exposure to rapamycin plus $\mathrm{CN}$-A than with rapamycin or $\mathrm{CN}$ A alone. Whereas individually rapamycin and $\mathrm{CN}-\mathrm{A}$ upregulated 61 and 46 genes and downregulated 33 and 26 genes, respectively, combined treatment with rapamycin and $\mathrm{CN}-\mathrm{A}$ upregulated 225 genes and downregulated 186 genes. Furthermore, 41 genes were upregulated more than threefold in
MCF-7 cells treated with rapamycin plus $\mathrm{CN}-\mathrm{A}$, although only one gene and eight genes were upregulated more than threefold in rapamycin-treated and CN-A-treated MCF-7 cells, respectively. These findings suggest that rapamycin and $\mathrm{CN}$ A can also induce synergistic effects on the induction of gene expression. Table 2 shows 25 genes that were highly upregulated (>3.4-fold) by rapamycin plus $\mathrm{CN}-\mathrm{A}$. Among these 25 upregulated genes, nine and 17 were upregulated $(>2$-fold) in rapamycin-treated and $\mathrm{CN}$-A-treated cells, respectively. TGFBI [23], BIK [24], cyclin $\mathrm{G}_{2}[25,26]$ and GRB7 [27] were upregulated by more than 5.8 -fold in MCF- 7 cells treated with rapamycin plus $\mathrm{CN}-\mathrm{A}$.

Table 3 shows 25 genes that were highly downregulated (gene expression ratio $<0.38$ ) by both rapamycin and $\mathrm{CN}-\mathrm{A}$. Thirteen genes were downregulated by less than one-third in cells treated with the combined treatment. In cells treated with $\mathrm{CN}-\mathrm{A}$ alone or the combined treatment, the expression of EGR3 [28] was decreased to about one-fifth of that in control MCF-7 cells. Table 4 shows the effects of rapamycin plus $\mathrm{CN}$ A on the expressions of several cell cycle regulatory genes. As mentioned above, the expression of cyclin $\mathrm{G}_{2}$ (gene expression ratio 6.08) was markedly induced, whereas the expressions of cyclin $E_{1}$ (gene expression ratio 0.44 ) and $E 2 F$ transcription factor 3 (gene expression ratio 0.42) were moderately downregulated in the rapamycin plus $\mathrm{CN}-\mathrm{A}$ treated cells.

\section{Time course of highly upregulated gene expression by} rapamycin plus cotylenin $A$

To confirm the results of the cDNA microarrray analysis, the expressions of highly upregulated genes were examined by RT-PCR. Figure 7a shows the time course patterns of gene expression of TGFBI, BIK, cyclin $\mathrm{G}_{2}$ and GRB7. Figure $7 \mathrm{~b}$ shows graphs of the relative levels of mRNA after normalization to GAPDH mRNA levels. These findings confirm the data from the cDNA microarray analysis. In these genes, the expression of cyclin $\mathrm{G}_{2}$ was increased fourfold at 3 hours after combined treatment and further increased with time $(>8$ fold at 24 hours). The expression of GRB7 was also induced by more than threefold at 3 hours after combined treatment, and the expression levels remained almost constant, at least until 24 hours. Expression of the TGFBI and BIK genes were markedly induced by the combined treatment after 12 hours. These genes were quickly and highly upregulated after the addition of rapamycin plus $\mathrm{CN}-\mathrm{A}$, and so they may play a crucial role in growth inhibition in human breast carcinoma cells treated with rapamycin plus $\mathrm{CN}-\mathrm{A}$.

\section{Effects of rapamycin and cotylenin $A$ on the in vivo growth of MCF-7 cells as xenografts}

The in vitro studies described above suggested that combined treatment with rapamycin and $\mathrm{CN}-\mathrm{A}$ should be more therapeutically effective than treatment with rapamycin or $\mathrm{CN}$ A alone. At day 20 after inoculation of human breast carcinoma 
Table 2

Upregulated genes in MCF-7 cells after exposure to rapamycin plus CN-A for 12 hours

\begin{tabular}{|c|c|c|c|c|}
\hline \multirow[b]{2}{*}{ GenBank number } & \multirow[b]{2}{*}{ Gene name } & \multicolumn{3}{|c|}{ Gene expression ratio } \\
\hline & & Rapamycin + CN-A & Rapamycin & CN-A \\
\hline NM 000358.1 & Transforming growth factor- $\beta$-induced 68 kDa (TGFBI) & 8.16 & 1.74 & 5.2 \\
\hline NM 001038.1 & Sodium channel, nonvoltage-gated $1 \alpha(\mathrm{SCNN} 1 \mathrm{~A})$ & 6.99 & 1.49 & 4.26 \\
\hline NM 002281.2 & Keratin, hair, basic-1 (KRTHB1) & 6.96 & 1.27 & $12.8^{\mathrm{a}}$ \\
\hline NM 001197.3 & BCL2-interacting killer (apoptosis-inducing; BIK) & 6.76 & 2.37 & 3.59 \\
\hline$\underline{\text { NM } 004354.1}$ & Cyclin $\mathrm{G}_{2}(\mathrm{CCNG} 2)$ & 6.08 & 3.07 & 3.22 \\
\hline NM 005310.1 & Growth factor receptor-bound protein 7 (GRB7) & 5.81 & 2.48 & 2.61 \\
\hline NM 020898.1 & KIAA1536 protein (KIAA1536) & 5.42 & 2.78 & 1.8 \\
\hline NM 030777.2 & Solute carrier family 2 , member 10 (SLC2A10) & 5.09 & 1.53 & 2.51 \\
\hline NM 005727.2 & Tetraspan 1 (TSPAN-1) & 4.61 & 1.54 & 1.76 \\
\hline NM 024709.1 & Hypothetical protein FLJ14146 (FLJ14146) & 4.55 & 1.8 & 2.53 \\
\hline NM 014376.1 & Cytoplasmic FMR1 interacting protein 2 (CYFIP2) & 4.21 & 2.43 & 1.66 \\
\hline NM 017644.1 & Hypothetical protein FLJ20059 (FLJ20059) & 4.09 & 1.51 & 1.2 \\
\hline NM 002166.1 & Inhibitor of DNA binding 2 (ID2) & 4.03 & 1.23 & 2.93 \\
\hline NM 006813.1 & Proline rich 2 (PROL2) & 3.87 & 2.8 & 1.9 \\
\hline NM 002885.1 & RAP1, GTPase activating protein 1 (RAP1GA1) & 3.81 & 1.56 & 2.51 \\
\hline NM 000755.2 & Carnitine acetyltransferase (CRAT) & 3.79 & 1.75 & 2.45 \\
\hline NM 031477.2 & Hypothetical protein MGC10500 (MGC10500) & 3.72 & 2.18 & 2.29 \\
\hline NM 012257.2 & HMG-box containing protein 1 (HBP1) & 3.7 & 1.67 & 1.55 \\
\hline NM 020169.2 & Latexin protein (LXN) & 3.68 & 2.49 & 2.40 \\
\hline NM 014417.2 & BCL2 binding component 3 (BBC3) & 3.55 & 1.82 & 2.18 \\
\hline NM 024642.2 & GalNAc-T12 (GALNT12) & 3.49 & 1.49 & 2.53 \\
\hline NM 016162.1 & Inhibitor of growth family, member 4 (ING4) & 3.47 & 1.98 & 1.73 \\
\hline NM 017673.2 & Chromosome 1 open reading frame 26 (C1orf26) & 3.45 & 1.44 & 2.93 \\
\hline NM 014353.2 & RAB26, member RAS oncogene family (RAB26) & 3.42 & 2.40 & 1.49 \\
\hline NM 005178.2 & B-cell CLL/lymphoma 3 (BCL3) & 3.39 & 1.05 & 3.31 \\
\hline
\end{tabular}

alncreased upper reliable levels. CN-A, cotylenin A.

MCF-7 cells the tumour volume (mean \pm standard deviation) was $119 \pm 59 \mathrm{~mm}^{3}$, and treatments were then started. We administered $0.1 \mu \mathrm{g}$ rapamycin/mouse every day and $100 \mu \mathrm{g}$ $\mathrm{CN}-\mathrm{A} / \mathrm{mouse}$ every other day. These treatments had no appreciable adverse effects on the mice. The combined treatment significantly inhibited the growth of MCF-7 cells as xenografts (Fig. 8). Injections of solvent alone did not inhibit the growth of MCF-7 cells in vivo (Fig. 8). At day 18 after treatment, the mean tumour volumes in untreated, rapamycin treated, $\mathrm{CN}-\mathrm{A}$ treated, and rapamycin $+\mathrm{CN}$-A treated nude mice were 1336 $\pm 332 \mathrm{~mm}^{3}, 659 \pm 181 \mathrm{~mm}^{3}, 848 \pm 237 \mathrm{~mm}^{3}$ and $245 \pm 62$ $\mathrm{mm}^{3}$, respectively. Although rapamycin and CN-A each significantly retarded tumour growth $(P<0.05)$, combined treatment induced the arrest of tumour growth. The treatment was continued for 18 days and then stopped, with follow up on day 48. All of the untreated, rapamycin treated and CN-A treated mice had a greater tumour burden at day 48. On the other hand, all mice treated with rapamycin plus $\mathrm{CN}-\mathrm{A}$ still had a much smaller tumour burden (data not shown), suggesting that the therapeutic effects were still maintained after treatment was terminated. These findings indicate that the combination of rapamycin and $\mathrm{CN}-\mathrm{A}$ is more therapeutically effective than treatment with rapamycin or $\mathrm{CN}-\mathrm{A}$ alone, and the combined treatment had a significant antitumour effect $(P$ $<0.001)$. 
Table 3

\begin{tabular}{|c|c|c|c|c|}
\hline \multirow[b]{2}{*}{ GenBank number } & \multirow[b]{2}{*}{ Gene name } & \multicolumn{3}{|c|}{ Gene expression ratio } \\
\hline & & Rapamycin + CN-A & Rapamycin & $\mathrm{CN}-\mathrm{A}$ \\
\hline$\underline{X M ~ 097230.3}$ & Similar to Cerebellin-like glycoprotein 1 (LOC147381) & 0.15 & 0.93 & 0.22 \\
\hline NM 006417.2 & Interferon-induced protein 44 (IFI44) & 0.18 & 0.62 & 0.24 \\
\hline XM 095568.5 & Hypothetical protein DKFZp762C1112 (DKFZp762C1112) & 0.19 & 1.13 & 0.29 \\
\hline$\underline{\text { NM } 006820.1}$ & Chromosome 1 open reading frame 29 (C1 orf29) & 0.20 & 0.83 & 0.21 \\
\hline NM 004430.1 & Early growth response 3 (EGR3) & 0.21 & 0.53 & 0.19 \\
\hline NM 024563.1 & Hypothetical protein FLJ14054 (FLJ14054) & 0.22 & 0.52 & 0.45 \\
\hline NM 017816.1 & Hypothetical protein FL20425 (LYAR) & 0.28 & 0.44 & 0.45 \\
\hline NM 004934.2 & Cadherin 18 , type $2(\mathrm{CDH} 18)$ & 0.28 & 1.10 & 0.20 \\
\hline NM 152454.1 & Hypothetical protein FLJ31461 (FL31461) & 0.29 & 1.11 & 0.29 \\
\hline$\underline{\mathrm{XM} 084501.3}$ & Hypothetical protein LOC143381 (LOC143381) & 0.29 & 1.36 & 0.24 \\
\hline NM 004704.1 & RNA, U3 small nucleolar interacting protein 2 (RNU3IP2) & 0.30 & 0.61 & 0.65 \\
\hline NM 006993.1 & Nucleophosmin/nucleoplasmin, 3 (NPM3) & 0.32 & 0.48 & 0.47 \\
\hline NM 003504.2 & CDC45 cell division cycle 45-like (S. cerevisiae) (CDC45L) & 0.32 & 0.48 & 0.69 \\
\hline XM 059689.2 & Similar to agCP15329 (LOC134111) & 0.34 & 0.69 & 0.38 \\
\hline NM 015179.1 & KIAA0690 protein (KIAA0690) & 0.35 & 0.56 & 0.71 \\
\hline NM 014520.1 & MYB binding protein (P160) 1a (MYBBP1A) & 0.35 & 0.53 & 0.62 \\
\hline$\underline{\mathrm{XM} 300777.1}$ & Similar to muscle protein (LOC348523) & 0.35 & 0.70 & 0.69 \\
\hline NM 032509.1 & RNA binding protein (LOC84549) & 0.35 & 0.47 & 0.75 \\
\hline NM 014503.1 & Downregulated in metastasis (DRIM) & 0.36 & 0.48 & 0.56 \\
\hline NM 000269.1 & Nonmetastatic cells 1 , protein (NM23A) expressed in (NME1) & 0.37 & 0.58 & 0.65 \\
\hline$\underline{\mathrm{XM} 050219.6}$ & Synaptopodin 2 (SYNPO2) & 0.37 & 0.93 & 0.57 \\
\hline XM 295865.1 & LOC340895 (LOC340895) & 0.37 & 1.34 & 0.33 \\
\hline NM 133263.1 & PPAR gamma coactivator $1 \beta(\mathrm{PERC})$ & 0.37 & 0.62 & 0.74 \\
\hline NM 002220.1 & Inositol 1,4,5-trisphosphate 3-kinase A (ITPKA) & 0.37 & 0.60 & 0.62 \\
\hline NM 015068.1 & Oaternally expressed 10 (PEG10) & 0.38 & 0.77 & 0.43 \\
\hline
\end{tabular}

$\mathrm{CN}-\mathrm{A}$, cotylenin $\mathrm{A}$.

\section{Discussion}

Rapamycin and its analogues are now in clinical trials as anticancer agents that may potently inhibit tumour cell proliferation [4-7]. We have reported that rapamycin or $\mathrm{CN}-\mathrm{A}$ alone could induce the differentiation of human myeloid leukaemia cells [12-16]. We previously screened the antiproliferative effects of differentiation inducers in myeloid leukaemia cells on several solid tumour cells. In this study, we found that combined treatment with rapamycin and $\mathrm{CN}-\mathrm{A}$ synergistically inhibited the proliferation of human breast cancer MCF-7 cells in vitro and had a marked antitumour effect on MCF-7 cells grown in nude mice. The combined treatment induced growth arrest of the cells at the $\mathrm{G}_{1}$ phase rather than apoptosis. Furthermore, the combined treatment strongly enhanced the expression of $\mathrm{E}$-cadherin. $\mathrm{CN}-\mathrm{A}$ and $\mathrm{CN}$-A plus rapamycin was able to induce SA- $\beta$ Gal activity, which is one of the markers of senescence of epithelial cells [21]. These findings suggest that the combined treatment may induce phenotypic changes toward cell senescence but not apoptosis.

In the present study we showed that the proliferation of human mammary carcinoma MCF-7 cells was synergistically inhibited by treatment with the combination of rapamycin and $\mathrm{CN}-\mathrm{A}$. Similar growth-inhibitory effects of rapamycin and CN-A were observed in two other human breast cancer cell lines (oestrogen receptor-positive T-47D cells and oestrogen receptor-negative MDA-MB-231 cells; Fig. 3a,b). These results suggest that the growth-inhibitory activity of rapamycin and CN-A may be independent of the presence of oestrogen receptor in tumour cells. Furthermore, similar growth-inhibitory 
Table 4

\begin{tabular}{|c|c|c|c|}
\hline \multirow[b]{2}{*}{ Gene name } & \multicolumn{3}{|l|}{ Gene expression ratio } \\
\hline & Rapamycin + CN-A & Rapamycin & $\mathrm{CN}-\mathrm{A}$ \\
\hline Cyclin $\mathrm{A}_{2}$ & 0.51 & 0.54 & 0.82 \\
\hline Cyclin $\mathrm{B}_{1}$ & 0.71 & 0.77 & 0.84 \\
\hline Cyclin $\mathrm{B}_{2}$ & 0.84 & 0.89 & 0.89 \\
\hline Cyclin $\mathrm{D}_{1}$ & 0.94 & 0.96 & 1 \\
\hline Cyclin $D_{3}$ & 0.86 & 0.7 & 1.09 \\
\hline Cyclin $\mathrm{E}_{1}$ & 0.44 & 0.67 & 0.66 \\
\hline Cyclin $E_{2}$ & 0.53 & 0.64 & 0.87 \\
\hline Cyclin $\mathrm{G}_{1}$ & 1.43 & 1.25 & 1.02 \\
\hline Cyclin $\mathrm{G}_{2}$ & 6.08 & 3.07 & 3.22 \\
\hline Cyclin-dependent kinase 2 (CDK2) & 0.58 & 0.78 & 0.83 \\
\hline Cyclin-dependent kinase 4 (CDK4) & 0.62 & 0.81 & 0.77 \\
\hline Cell division cycle 2 (CDC2) & 0.62 & 0.7 & 0.85 \\
\hline P53 & 1.37 & 1.52 & 1.32 \\
\hline P21 (Cip1) & 0.85 & 0.83 & 1.03 \\
\hline P27 (Kip1) & 1.65 & 1.39 & 1.18 \\
\hline Retinoblastoma 1 (RB1) & 1.08 & 1.09 & 1.04 \\
\hline Retinoblastoma-like 1 (p107) & 0.53 & 0.67 & 0.87 \\
\hline Retinoblastoma-like 2 ( $\mathrm{p} 130)$ & 1.96 & 2.18 & 1.07 \\
\hline E2F transcription factor $3(\mathrm{E} 2 \mathrm{~F} 3)$ & 0.42 & 0.86 & \\
\hline E2F transcription factor $5, \mathrm{p} 130$-binding (E2F5) & 0.96 & 1.21 & 0.81 \\
\hline E2F transcription factor 6 (E2F6) & 0.62 & 0.70 & 0.65 \\
\hline
\end{tabular}

CN-A, cotylenin A.

effects of rapamycin and $\mathrm{CN}-\mathrm{A}$ were also observed in human non-small-cell lung carcinoma A549 and Lu99 cells (data not shown) and human promyelocytic leukaemia NB-4 cells (Fig. 3c), but not in human monocytic leukaemia THP-1 cells or human ovary carcinoma OVCAR-5 cells. Rapamycin barely inhibited the proliferation of THP-1 cells and OVCAR- 5 cells, although $\mathrm{CN}-\mathrm{A}$ dose dependently inhibited the proliferation of THP-1 cells and OVCAR-5 cells (data not shown). These results indicate that the synergistic growth-inhibitory effects of rapamycin plus $\mathrm{CN}-\mathrm{A}$ are observed not only in MCF-7 cells but also in other cancer cells, and suggest that moderate to low sensitivity, but not insensitivity, to rapamycin is necessary to exert the synergistic growth-inhibitory effects of rapamycin plus $\mathrm{CN}-\mathrm{A}$ in cancer cells.
Previous papers have demonstrated that rapamycin induces the inhibition of cell proliferation and $\mathrm{G}_{1}$ arrest possibly due to downregulation of the expressions of cyclin $D_{1}$ and c-myc, and upregulation of the expressions of $\mathrm{p} 21^{\mathrm{Cip} 1}$ and $\mathrm{p} 27^{\mathrm{Kip}} 1$ through rapamycin-induced mTOR inhibition in various cancer cells, including MCF-7 cells [5,6]. Furthermore, various agents such as PM-3 (a benzo- $\gamma$-pyran derivative), flavopiridol, 2-(4-amino3-methylphenyl)-5-fluorobenzothiazole (5F-203; an anticancer drug) and oncostatin M induced growth arrest of MCF-7 cells and inhibited the expression of cyclin $D_{1}$ and/or c-myc, or upregulated the expression of $\mathrm{p} 21^{\mathrm{Cip} 1}$ at the transcriptional level [21,29-31]. These reports suggest that downregulation of the expressions of cyclin $D_{1}$ and c-myc, and up-regulation of the expressions of $\mathrm{p} 21^{\mathrm{Cip} 1}$ and $\mathrm{p} 27^{\mathrm{Kip} 1}$ are important to growth arrest of MCF-7 cells. 
Figure 7

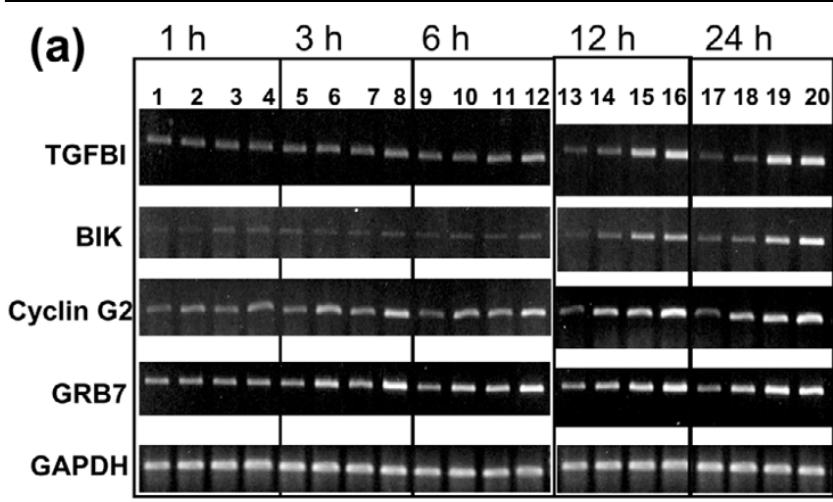

(b)
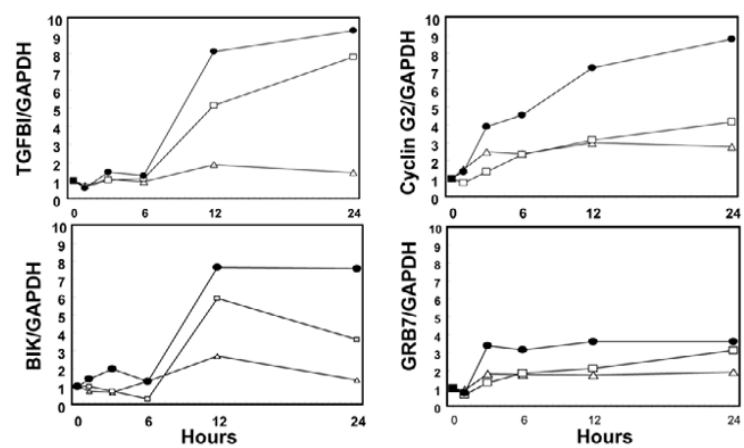

Time courses of TGFBI, BIK, cyclin $\mathrm{G}_{2}$ and GRB7 mRNA expression in MCF-7 cells. (a) MCF-7 cells were treated without (lanes 1, 5, 9, 13 and 17) or with $0.5 \mathrm{ng} / \mathrm{ml}$ rapamycin (lanes $2,6,10,14$ and 18), $10 \mu \mathrm{g} /$ $\mathrm{ml} \mathrm{CN}$-A (lanes 3, 7, 11, 15 and 19), or $0.5 \mathrm{ng} / \mathrm{ml}$ rapamycin plus 10 $\mu \mathrm{g} / \mathrm{ml}$ CN-A (lanes 4, 8, 12, 16 and 20) for 1, 3, 6, 12 and 24 hours. Expression of mRNAs was examined by RT-PCR analysis. (b) Graphs depict the relative levels of $m R N A$ after normalization to GAPDH mRNA levels in Fig. $5 \mathrm{a}$. Cells were treated with $0.5 \mathrm{ng} / \mathrm{ml}$ rapamycin (white triangle) or $10 \mu \mathrm{g} / \mathrm{ml} \mathrm{CN-A} \mathrm{(white} \mathrm{square),} \mathrm{or} \mathrm{both} \mathrm{combined} \mathrm{(black} \mathrm{cir-}$ cle). BIK, BCL2-interacting killer; CN-A, cotylenin A; GAPDH, glyceraldehyde-3-phosphate dehydrogenase; GRB, growth factor receptor-bound; TGFBI, transforming growth factor- $\beta$-induced $68 \mathrm{kDa}$ protein.

In the present study, at the doses used, neither rapamycin nor $\mathrm{CN}-\mathrm{A}$ alone induced $\mathrm{G}_{1}$ arrest or significantly affected the expressions of cyclin D, p21Cip1, p27Kip1 or c-myc. Furthermore, even when rapamycin in combination with $\mathrm{CN}-\mathrm{A}$ induced $\mathrm{G}_{1}$ arrest of MCF-7 cells, the expressions of these genes were not significantly affected. These findings suggest that other critical genes are important for the induction of growth arrest of MCF-7 cells by rapamycin plus CN-A. Alternatively, the synergistic effects of rapamycin plus CN-A may be exerted by an mTOR-independent pathway. However, this possibility is extremely unlikely because the synergistic effects of rapamycin and $\mathrm{CN}-\mathrm{A}$ could be blocked by the presence of FK506 on MCF-7 cells (data not shown). It is believed that rapamycin and FK506, which have structural similarities, compete for binding to FKBP12. However, only the complex between rapamycin and FKBP12 is able to bind to mTOR, thereby inhibiting mTOR's role in protein synthesis and the cell cycle [4-7].
Figure 8

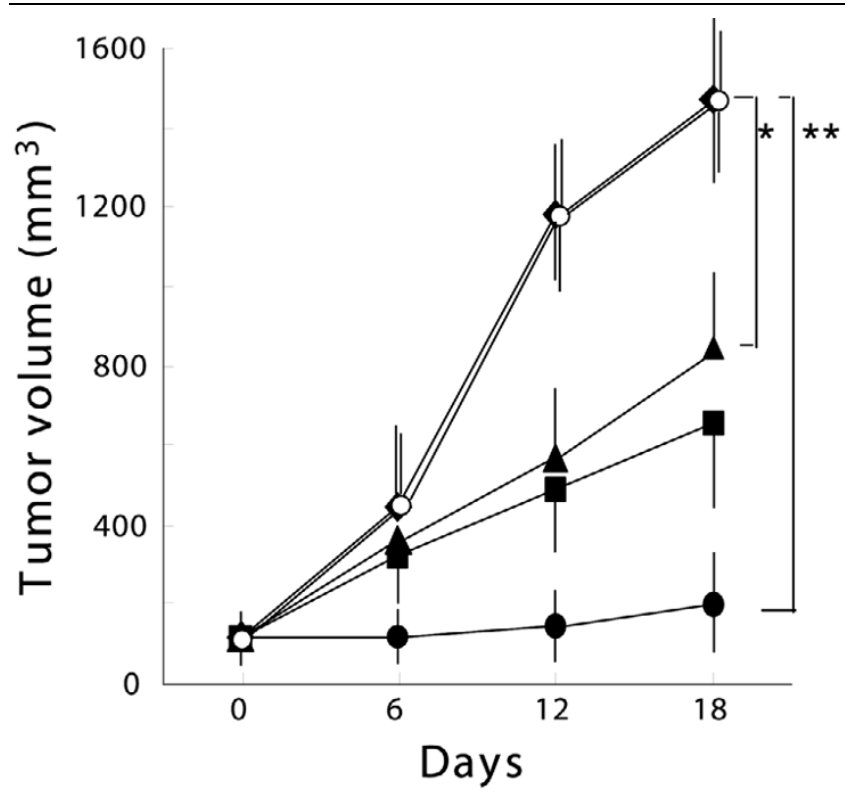

Effects of rapamycin and CN-A on the growth of MCF-7 cells as xenografts. Mice were given a daily intraperitoneal injection of $100 \mathrm{ng}$ rapamycin (black square, black circle) and/or subcutaneous injection of $100 \mu \mathrm{g}$ of CN-A (black triangle, black circle) every other day. Values are expressed as mean \pm standard deviation of 20 mice. Black diamond, untreated mice; white circle, mice treated with solvent alone. CN-A, cotylenin $A ;{ }^{*}, p<0.05 ;{ }^{* *}, p<0.001$.

Among highly modulated genes induced by rapamycin plus CN-A, we postulate that cyclin $\mathrm{G}_{2}$, TGFBI, BIK, GRB7 and EGR3 may play important roles in the induction of the growth inhibition of MCF-7 cells by rapamycin plus CN-A. Cyclin $\mathrm{G}_{2}$, together with cyclin $G_{1}$ and cyclin I, defines a novel cyclin family expressed in terminally differentiated tissues. Cyclin $G_{2}$ expression is upregulated as cells undergo cell cycle arrest or apoptosis in response to inhibitory stimuli independent of p53 $[25,26,32]$. We found a marked induction (>6-fold) in cyclin $\mathrm{G}_{2}$ in rapamycin plus CN-A treated MCF-7 cells (Table 2, Fig. 7). The expression of cyclin $\mathrm{G}_{2}$ was significantly upregulated at 1 hour after combined treatment and then further upregulated with time (>8-fold at 24 hours; Fig. 7). Frasor and coworkers [33] reported that in oestrogen-treated MCF-7 cells, the expression of cyclin $\mathrm{G}_{2}$ was quickly downregulated. Maxwell and coworkers [34] reported a microarray analysis after treatment of MCF-7 cells with 5-fluorouracil, and found that 5fluorouracil upregulated the expression of cyclin $G$, although they did not discriminate between cyclin $G_{1}$ and cyclin $G_{2}$. These previous reports and our findings suggest that, in human breast cancer MCF- 7 cells, cyclin $\mathrm{G}_{2}$ may be a key negative regulator of cell cycle progression.

TGFBI is an extracellular matrix protein whose expression can be induced by transforming growth factor- $\beta$ [23]. Previous reports $[23,35,36]$ have suggested that TGFBI is involved in cell growth, cell differentiation, cell adhesion and apoptosis, 
and that it may act as a tumour suppressor. Rapamycin plus CN-A strongly induced TGFBI expression in MCF-7 cells. Because the expression of transforming growth factor- $\beta_{3}$ was upregulated 2.2-fold in these cells at 12 hours after treatment with rapamycin plus $\mathrm{CN}-\mathrm{A}$ (microarray data; data not shown), it will be interesting to determine whether the marked induction of TGFBl expression is mediated by the induction of transforming growth factor- $\beta_{3}$ gene expression.

$\mathrm{BIK}$ is a BH3-only proapoptotic protein and forms heterodimers with various antiapoptotic proteins, including $\mathrm{Bcl}-2$ and $\mathrm{Bcl}-\mathrm{X}_{\mathrm{L}}$ [24]. BIK triggers apoptosis through a p53-independent pathway. Systemically administrated BIK inhibited the growth of human breast cancer cells implanted in nude mice and prolonged the life span of the treated animals [37]. Although we did not observe evidence of induction of apoptosis in combination-treated MCF-7 cells, upregulated BIK may contribute to the suppression of growth in MCF-7 cells.

GRB7 is an adaptor molecule that mediates signal transduction from multiple cell surface receptors to various downstream signalling pathways. GRB7 and its related family members GRB10 and GRB14 share a conserved molecular architecture including Src homology $2(\mathrm{SH} 2)$ and pleckstrin homology $(\mathrm{PH})$ domains. GRB7 has been implicated to be a downstream mediator of integrin-FAK signal pathways in the regulation of cell migration [27], whereas recent studies have suggested that GRB10 and GRB14 play important roles in cell proliferation $[38,39]$. In the present study, we found that rapamycin plus $\mathrm{CN}-\mathrm{A}$ specifically upregulated expression of the GRB7 gene but not the expressions of other genes in this family (Table 2, data not shown). Because the biological roles and molecular mechanisms of this family of genes are still not well understood, it is possible that the specific and early upregulation of GRB7 gene expression may contribute to the combined treatment-induced inhibition of the growth of MCF7 cells.

EGR3 is an immediate-early and zinc-finger transcription factor [28]. Oestradiol-treated MCF-7 cells exhibited rapid and marked induction of EGR3 gene expression $[33,40]$. The EGR3 gene is a critical transcription factor for Fas ligand expression in MCF-7 cells as well as T cells [40,41]. Inoue and coworkers [40] suggested that EGR3 plays an important role in the oestrogen-dependent induction of the immune evasion system in oestrogen receptor-positive breast cancer. The present data showed that the expression of EGR3 was markedly downregulated by $\mathrm{CN}-\mathrm{A}$ alone or rapamycin plus CN-A in MCF-7 cells. Thus, MCF-7 cells in which expression of the EGR3 gene is downregulated might be more susceptible to immune surveillance in vivo.

We showed that rapamycin and $\mathrm{CN}-\mathrm{A}$ cooperatively induced growth arrest in breast carcinoma MCF-7 cells in vitro, and that treatment with the combination of rapamycin and $\mathrm{CN}-\mathrm{A}$ more strongly inhibited the growth of MCF-7 cells as xenografts in vivo than did treatment with rapamycin or $\mathrm{CN}-\mathrm{A}$ alone. The combined treatment also induced the arrest of tumour growth (Fig. 8). Even when treatment was continued for 18 days and then stopped, with follow up on day 48 all of the mice treated with rapamycin plus $\mathrm{CN}-\mathrm{A}$ still had a much smaller tumour burden (data not shown). These results suggest that the combination of rapamycin and $\mathrm{CN}-\mathrm{A}$ also induced growth arrest of the cells at the $G_{1}$ phase in vivo and then might induce cell senescence. This treatment has no apparent effects on mice (with regard to body weight and behaviour). Taken together, these findings suggest that treatment with the combination of rapamycin and $\mathrm{CN}-\mathrm{A}$ may be a promising therapeutic strategy for human breast cancer, although the mechanisms underlying the synergistic action of this combined treatment require further investigation.

\section{Conclusion}

We found that rapamycin and CN-A, a novel inducer of the differentiation of myeloid leukaemia cells, synergistically inhibited the proliferation of mammary carcinoma MCF-7 cells. This combined treatment induced growth arrest of the cells at the $\mathrm{G}_{1}$ phase, rather than apoptosis, and induced activity of SA$\beta \mathrm{Gal}$, which is one of the markers of senescence of epithelial cells. Although the expressions of p53, p21 Cip1, p27Kip1 and cyclin $D_{1}$ mRNAs did not significantly change, we found that expressions of several genes such as cyclin $\mathrm{G}_{2}$, TGFBI, BIK, GRB7 and ERG3 were markedly modulated in MCF-7 cells treated with rapamycin plus $\mathrm{CN}-\mathrm{A}$. Furthermore, the combined treatment with rapamycin and $\mathrm{CN}-\mathrm{A}$ significantly inhibited the growth of MCF-7 cells as xenografts without apparent adverse effects, suggesting this combination may have therapeutic value in treating breast cancer.

\section{Competing interests}

The authors declare that they have no competing interests.

\section{Authors' contributions}

TK participated in the design of the study and carried out in vitro testing and data analysis, and prepared the manuscript. JO-K contributed to its critical revision for important intellectual content. NK and TS participated in the preparation of $\mathrm{CN}$ $\mathrm{A}$ and its derivatives. $\mathrm{YH}$ contributed to the design of the study and carried out in vivo experiments.

\section{Acknowledgements}

This work was supported in part by grants from the Ministry of Education, Culture, Sports, Science and Technology, Japan and the Ministry of Health, Welfare and Labor, Japan.

\section{References}

1. Jemal A, Clegg LX, Ward E, Ries LAG, Wu X, Jamison PM, Wingo $\mathrm{P} A$, Howe HE, Anderson RN, Edwards BK: Annual report to nation on the states of cancer, 1975-with a special feature regarding survival. Cancer 2004, 101:3-27.

2. Christensen GL, Jepsen JS, Fog CK, Christensen IJ, Lykkesfeldt $A E$ : Sequential versus combined treatment of human breast cancer cells with antiestrogens and the vitamin $D$ analogue 
EB1089 and evaluation of predictive markers for vitamin D treatment. Breast Cancer Res Treat 2004, 85:53-63.

3. Dabrosin C, Johansson A, Olinger K: Decreased secretion of cathepsin $D$ in breast cancer in vivo by tamoxifen: mediated by the mannose-6-phosphate/IGF-II receptor? Breast Cancer Res Treat 2004, 85:229-238.

4. Yu K, Toral-Barza L, Discafani C, Zhang W-G, Skotnicki J, Frost P, Gibbons JJ: mTOR, a novel target in breast cancer: the effect of $\mathrm{CCl}-779$, an mTOR inhibitor, in preclinical models of breast cancer. Endocr Relat Cancer 2001, 8:249-258.

5. Noh W-C, Mondesire WH, Peng J, Jian W, Zhang H, Dong J, Mills GB, Hung M-C, Meric-Bernstam F: Determinants of rapamycin sensitivity in breast cancer cells. Clin Cancer Res 2004, 10:1013-1023.

6. Huang S, Houghton PJ: Inhibitors of mammalian target of rapamycin as novel antitumor agents. Curr Opin Investig Drugs 2002, 3:295-304.

7. Huang S, Houghton P: Targeting mTOR signaling for cancer therapy. Curr Opin Pharmacol 2003, 3:371-377.

8. Okabe-Kado J, Hayashi M, Honma Y, Hozumi M: Enhancement by hemin on the sensitivity of K562 human leukemic cells to 1- $\beta$ D-arabinofuranocylcytosine. Cancer Res 1986, 46:1239-1243.

9. Okabe-Kado J, Hayashi M, Honma Y, Hozumi M, Tsuruo T: Inhibition by erythroid differentiation factor (activin A) of p-glycoprotein expression in multidrug-resistant human K562 erythroleukemia cells. Cancer Res 1991, 51:2582-2586.

10. Sassa T, Tojyo T, Munakata K: Isolation of a new plant growth substance with cytokinin-like activity. Nature 1970, 227:379.

11. Sassa T, Ooi T, Nukina M, lkeda M, Kato N: Structural confirmation of cotylenin A, a novel fusicoccane-diterpene glycoside with potent plant growth-regulating activity from Cladosporium fungus sp. 501-7W. Biosci Biotechnol Biochem 1998, 62:1815-1818.

12. Asahi K, Honma $Y$, Hazeki K, Sassa T, Kubohara $Y$, Sakurai A, Takahashi N: Cotylenin A, a plant-growth regulator, induces differentiation in murine and human myeloid leukemia cells. Biochem Biophys Res Commun 1997, 238:758-763.

13. Yamamoto-Yamaguchi $Y$, Yamada K, Ishii Y, Asahi K, Tomoyasu S, Honma $Y$ : Induction of monocytic differentiation of myeloid leukaemia cells by cotylenin $\mathrm{A}$, a plant growth regulator. $\mathrm{Br} \mathrm{J}$ Haematol 2001, 112:697-705.

14. Honma $Y$ : Cotylenin A: a plant growth regulator as a differentiation-inducing agent against myeloid leukemia. Leuk Lymphoma 2002, 43:1169-1178.

15. Yamada K, Honma Y, Asahi K, Sassa T, Hino K, Tomoyasu S: Differentiation of human acute myeloid leukaemia cells in primary culture in response to cotylenin $A$, a plant growth regulator. Br J Haematol 2001, 114:814-821.

16. Honma Y, Ishii $Y$, Sassa T, Asahi K: Treatment of human promyelocytic leukemia in the SCID mouse model with cotylenin A, an inducer of myelomonocytic differentiation of leukemia cells. Leuk Res 2003, 27:1019-1025.

17. Honma Y, Ishii Y, Yamamoto-Yamaguchi Y, Sassa T, Asahi K: Cotylenin $A$, a differentiation-inducing agent, and IFN- $\alpha$ cooperatively induce apoptosis and have an antitumor effect on human non-small cell lung carcinoma cells in nude mice. Cancer Res 2003, 63:3659-3666.

18. Chou TC, Talalay P: Quantitative analysis of dose-effect relationship: the combined effects of multiple drugs or enzyme inhibitors. Adv Enzyme Regul 1984, 22:27-55

19. Dimri GP, Lee X, Basile G, Acosta M, Scott G, Roskelley C, Medrano EE, Linskens M, Rubeji I, Perrira-Smith O, et al.: A biomarker that identifies senescent human cells in culture and in aging skin in vivo. Proc Natl Acad Sci USA 1995, 92:9363-9367.

20. Nakamaki T, Okabe-Kado J, Yamamoto-Yamaguchi Y, Hino K, Tomoyasu S, Honma Y, Kasukabe T: Role of MmTRA1b/phospholipid scramblase 1 gene expression in the induction of differentiation of human myeloid leukemia cells into granulocytes. Exp Hematol 2002, 30:421-429.

21. Li C, Shridhar K, Liu J: Molecular characterization of oncostatin $M$-induced growth arrest of MCF cells expressing a temperature-sensitive mutant of p53. Breast Cancer Res Treat 2003, 80:23-37.

22. Gera JF, Mellinghoff IK, Shi Y, Rettig MB, Trans C, Hsu J, Sawyers $\mathrm{CL}$, Lichtenstein AK: AKT activity determines sensitivity to mammalian target of rapamycin (mTOR) inhibitors by regulat- ing cyclin D1 and c-myc expression. J Biol Chem 2004, 279:2737-2746.

23. Skonier J, Bennett K, Rothwell V, Kosowski S, Plowman G, Wallace $P$, Edelhoff $S$, Disteche $C$, Neubauer M, Marquaedt $H$ : beta ig-h3: a transforming growth factor-beta-responsive gene encoding a secreted protein that inhibits cell attachment in vitro and suppresses the growth of $\mathrm{CHO}$ cells in nude mice. DNA Cell Biol 1994, 13:571-584.

24. Boyd JM, Gallo GJ, Elangovan B, Houghton AB, Malstrom S, Avery BJ, Ebb RG, Subramanian T, Chittenden T, Lutz RJ: Bik, a novel death-inducing protein shares a distinct sequence motif with $\mathrm{Bcl}-2$ family proteins and interacts with viral and cellular survival-promoting proteins. Oncogene 1995, 11:1921-1928.

25. Horne MC, Donaldson KL, Goolsby GM, Tran D, Mulheisen M, Hell JW, Wahl AF: Cyclin G2 is up-regulated during growth inhibition and $B$ cell antigen receptor-mediated cell cycle arrest. J Biol Chem 1997, 272:12650-12661.

26. Martinez-Gac L, Marques M, Garcia Z, Campanero MR, Carrera AC: Control of cyclin G2 mRNA expression by forkhead transcription factors: novel mechanism for cell cycle control by phosphoinositide 3-kinase and forkhead. Mol Cell Biol 2004 , 24:2181-2189.

27. Shen T-L, Han DC, Guan J-L: Association of Grb7 with phosphoinositides and its role in the regulation of cell migration. $J$ Biol Chem 2002, 277:29069-29077.

28. Patwardhan S, Gashler A, Siegel MG, Chang LC, Joseph LJ, Shows TB, Le Beau MM, Sukhatme VP: EGR3, a novel member of the Egr family of genes encoding immediate-early transcription factors. Oncogene 1991, 6:917-928.

29. Luo J, Soh J, Xing W, Mao Y, Matsuno T, Weinstein IB: PM-3, a benzo- $\gamma$-pyran derivative isolated propolis, inhibits growth of MCF-7 human breast cancer cells. Anticancer Res 2001, 21:1665-1672.

30. Carlson B, Lahusen T, Singh S, Loaiza-Perez A, Worland PJ, Pestell R, Albanese C, Sausville WA, Senderowicz AM: Down-regulation of cyclin D1 by transcriptional repression in MCF-7 human breast carcinoma cells induced by flavopiridol. Cancer Res 1999, 59:4634-4641.

31. Monks A, Harris E, Hose C, Connelly J, Sausville ED: Genotoxic profiling of MCF-7 breast cancer cell line elucidates gene expression modifications underlying toxicity of the anticancer drug 2-(4-amino-3-methylphenyl)-5-fluorobenzothiazole. Mol Pharmacol 2003, 63:766-772.

32. Bennin DA, Arachchige Don AS, Brake T, McKenzie JL, Rosenbaum H, Ortiz L, DePaoli-Roach AA, Horne MC: Cyclin G2 associates with protein phosphatase $2 A$ catalytic and regulatory $B$ subunits in active complexes and induces nuclear aberrations and a G1/S phase cell cycle arrest. J Biol Chem 2002, 277:27449-27467.

33. Frasor J, Danes JM, Komm B, Chang KCN, Lyttle CR, Katzenellenbogen BS: Profiling of estrogen up- and down-regulated gene expression in human breast cancer cells: insights into gene networks and pathways underlying estrogenic into control of proliferation and cell phenotype. Endocrinology 2003, 144:4562-4574.

34. Maxwell PJ, Longley DB, Latif T, Boyer J, Allen W, Lynch M, McDermott U, Harkin DP, Allegra CJ, Johnston PG: Identification of 5fluorouracil-inducible target genes using CDNA microarray profiling. Cancer Res 2003, 63:4602-4606.

35. Dieudonne SC, Kerr JM, Xu T, Sommer B, DeRubeis AR, Kuznetsov SA, Kim IS, Gehron Robey P, Young MF: Differential display of human marrow stroma cells reveals unique mRNA expression patterns in response to dexamethasone. $J \mathrm{Cell}$ Biochem 1999, 76:231-243.

36. Kim J, Kim S, Jeong H, Lee B, Choi J, Park R, Park J, Kim I: RGD peptides released from $\beta$ ig-h3, a TGF- $\beta$-induced cell adhesive molecule, mediate apoptosis. Oncogene 2003, 22:2045-2053.

37. Zou Y, Peng H, Zhou B, Wen Y, Wang S, Tsai E, Hung M: Systemic tumor suppression by the proapoptotic gene bik. Cancer Res 2002, 62:8-12.

38. Shen TL, Guan JL: Grb7 in intracellular signaling and its role in cell regulation. Front Biosci 2004, 9:192-200.

39. Kairouz R, Parmar J, Lyons RJ, Swarbrick A, Musgrove EA, Daly RJ: Hormonal regulation of the Grb14 signal modulator and its role in cell cycle progression of MCF-7 human breast cancer cells. J Cell Physiol 2005, 203:85-93. 
Breast Cancer Research Vol 7 No 6 Kasukabe et al.

40. Inoue A, Omoto Y, Yamaguchi Y, Kiyama R, Hayashi S: Transcription factor EGR3 is involved in the estrogen-signaling pathway in breast cancer cells. $J$ Mol Endocrinol 2004, 32:649-661.

41. Mittelstadt PR, Ashwell JD: Cyclosporin A-sensitive transcription factor EGR-3 regulates Fas ligand expression. Mol Cell Biol 1998, 18:3744-3751. 